\author{
Sabina Wieruszewska-Duraj \\ ORCID: 0000-0003-4402-957X \\ Uniwersytet Przyrodniczo-Humanistyczny w Siedlcach \\ Wydział Nauk Społecznych
}

\title{
PROJEKTOWANIE UNIWERSALNE PRZESTRZENI W PRZEDSZKOLU JAKO ODPOWIEDŹ NA SZCZEGÓLNE POTRZEBY DZIECI
}

\author{
Universal design of space in kindergarten \\ as a response to the specific needs of children
}

https://doi.org/10.34739/sn.2021.21.03

\begin{abstract}
Abstrakt: Projektowanie uniwersalne przedszkoli powinno iść w kierunku tworzenia w pełni dostępnej przestrzeni publicznej, która spełni oczekiwania wszystkich dzieci, bez względu na wiek, stan zdrowia czy ograniczenia mobilności lub percepcji. Powszechna dostępność przestrzeni warunkuje bowiem prawidłowy rozwój jednostki. Dla poprawy bezpieczeństwa i ograniczenia wykluczenia społecznego dzieci, w tym dzieci ze szczególnymi potrzebami edukacyjnymi, należy dążyć do kształtowania środowiska opartego na zasadach projektowania uniwersalnego. W artykule przedstawione zostały założenia w zakresie podstaw projektowania i aranżacji przestrzeni dla dziecka w przedszkolu, uwzględniające jego potrzeby, oraz omówione - zagadnienia związane z likwidacją barier przestrzennych, które zmniejszają bezpieczeństwo i niezależność w rozwoju osobistym dziecka.
\end{abstract}

Słowa kluczowe: projektowanie uniwersalne, aranżacja przestrzeni w przedszkolu, dostępność, dziecko w wieku przedszkolnym, specjalne potrzeby

\begin{abstract}
Universal design of space in a kindergarten should be aimed at creating full accessibility of public space that will meet the expectations of all children, regardless of age, health condition or limitations of mobility or perception. The universal availability of space determines the proper development of an individual. In order to improve the safety and limit the social exclusion of children, including children with special educational needs, one should strive to shape an environment based on the principles of universal design. The article presents the assumptions for the design and arrangement of a child's space in a kindergarten taking into account its needs, and discusses issues related to the elimination of spatial barriers that increase safety and independence in the child's personal development.
\end{abstract}


Keywords: universal design, space arrangement in kindergarten, accessibility, preschool child, special needs

Projektowanie uniwersalne po raz pierwszy zdefiniował Ronald Mace, architekt, który - będąc osobą poruszającą się od urodzenia na wózku stwierdził, że jest to projektowanie produktów i środowiska, które mogą być użytkowane w możliwie największym stopniu - bez potrzeby specjalistycznej adaptacji - przez wszystkich ludzi ${ }^{1}$. Zawarta w art. 2 Konwencji ONZ o prawach osób niepełnosprawnych definicja projektowania uniwersalnego rozszerzona została o „konieczność” projektowania programów i usług w taki sposób, by były użyteczne dla wszystkich, w możliwie największym stopniu - nie wykluczając jednocześnie projektowania dodatkowych pomocy technicznych, uwzględniających potrzeby szczególnych grup osób z niepełnosprawnością, jeżeli jest to im niezbędne do samodzielnego funkcjonowania [Dz. U. 2012 r. poz. 1169].

W myśl idei projektowania uniwersalnego - i zgodnie z art. 2 Ustawy o zapewnianiu dostępności osobom ze szczególnymi potrzebami - jako osobę ze szczególnymi potrzebami będziemy traktować każdą osobę, która ze względu na swoje cechy zewnętrzne lub wewnętrzne, albo ze względu na okoliczności, w których się znajduje, musi podjąć dodatkowe działania lub zastosować dodatkowe środki w celu przezwyciężenia bariery, aby uczestniczyć w różnych sferach życia na równi z innymi osobami [Dz.U. 2019 poz. 1696]. Podmiotem takim jest dziecko, którego specyfika rozwoju plasuje je na szczególnej pozycji ze względu na konieczność respektowania i spełniania jego potrzeb. Zakładając, że projektowanie dostępnej przestrzeni wspólnej powinno prowadzić do podniesienia jej funkcjonalności nie tylko na poziomie potrzeb fizycznych, ale również psychologicznych i emocjonalnych [Wysocki 2012, s. 444], bardzo istotna staje się jej aranżacja w taki sposób, by zapewnić dziecku harmonijny rozwój i spełnienie potrzeb w sferze ruchowej, emocjonalnej i psychologicznej. Przestrzeń przedszkolna zaprojektowana $w$ duchu koncepcji projektowania

\footnotetext{
${ }^{1}$ Definicję zaczerpnięto ze strony internetowej: https://archiwum.ncbr.gov.pl/fileadmin/ POWER/03.05...PUN_19/zalacznik_nr_13_Modele_projektowania_uniwersalnego.pdf [data dostępu: 23.07.2021].
} 
uniwersalnego podnosi zatem dzieciom uczęszczającym do placówki jakość życia. Dzieciom z niepełnosprawnościami przestrzeń taka gwarantuje realizację podstawowych praw człowieka, prawo do niezależności i samostanowienia.

Definicja projektowania uniwersalnego została oparta na siedmiu wypracowanych i przyjętych zasadach, które możemy odnieść do projektowania przestrzeni dostępnej dla dziecka. Są to następujące zasady:

1. Równość w dostępie - oznacza możliwość używania danego produktu przez osoby o zróżnicowanych możliwościach, przy czym każda osoba, niezależnie od doświadczanych przez nią ograniczeń, ma prawo do używania danego produktu, a jeśli nie jest to możliwe, należy dla niej zaplanować i zaprojektować możliwości równorzędne i równie atrakcyjne. Równość w dostępie określa, że każde dziecko, niezależnie od poziomu sprawności/ niepełnosprawności, posiadania czy braku kompetencji, ma prawo dostępu do edukacji o jednakowej jakości. Przykładem niekomfortowej praktyki w tym względzie jest korzystanie na zajęciach z biało-czarnych kserokopii kart pracy, pierwotnie dostępnych w kolorze. „Robienie kserówek” jest zazwyczaj dla dziecka demotywujące, a efekty pracy nie tak dobre jak wtedy, kiedy mogłoby skorzystać z kolorowych kart pracy.

2. Elastyczność użycia - wiąże się z uwzględnieniem szerokiego zakresu indywidualnych preferencji, które mogą być różne w zależności np. od typu lateralizacji użytkownika, tempa jego pracy, preferowanego sposobu wykonywania czynności itp. Elastyczność użycia to możliwość wykonania zadania w różnym czasie oraz różnorodnej formie (np. dziecko może wykonać ćwiczenie w wersji papierowej lub elektronicznej).

3. Intuicyjność w używaniu - zgodnie z nią produkt powinien być dla wszystkich łatwy w użyciu - niezależnie od poziomu doświadczenia użytkownika, zakresu jego wiedzy, poziomu koncentracji, uwagi czy komunikacji językowej. Intuicyjność użycia wskazuje na konieczność takiego przygotowania zadania, aby nie wymagało ono skomplikowanej instrukcji. Polecenia do zadań dla dzieci powinny być krótkie, przekazane w języku w pełni dla nich zrozumiałym. 
4. Dostępność percepcyjna - zakłada czytelność informacji i wielość kanałów przekazu, aby informacja była dostępna dla osób z trudnościami w zakresie percepcji wzrokowej czy słuchowej. Zasada dostępności informacji odnosi się przede wszystkim do dostępności percepcyjnej i może być przedstawiona w postaci hasła dobrze znanego nauczycielom edukacji przedszkolnej: „temu, co wypowiedziane, towarzyszy obraz, obrazowi - słowo".

5. Tolerancja na błędy - według niej popełnienie błędu w obsłudze nie generuje istotnych uszkodzeń i zagrożeń; elementy najczęściej potrzebne są najbardziej widoczne, a części niebezpieczne - odpowiednio zabezpieczone lub izolowane. Zasada tolerancji na błędy ma swoje źródło w przekonaniu, że błąd/pomyłka dziecka to ważna sytuacja dydaktyczna, dzięki której może ono kontynuować drogę do nabywania wiedzy i kompetencji w danym obszarze. Radząc sobie w sytuacjach trudnych wzmacnia także zasób swych kompetencji społecznych i emocjonalnych. Z tego względu uznaje się, że popełnianie błędów jest nieodłącznym elementem uczenia się, a zadaniem nauczyciela jest zadbanie o to, by stworzyć przestrzeń i czas na poprawienie pracy czy ponowne wykonanie zadania. Dotyczy to zarówno zapewnienia odpowiedniej przestrzeni czasowej, jak i - np. - wystarczająco dużej przestrzeni na karcie pracy tak, aby dziecko mogło dotrzeć do poprawnego rozwiązania.

6. Mały wysiłek fizyczny - oznacza, że produkt może być używany nawet przy niewielkim nakładzie wysiłku fizycznego. Dla przykładu, dzieci ze specjalnymi potrzebami edukacyjnymi zazwyczaj są osobami męczliwymi, z trudnościami w zakresie koncentracji uwagi. Nauczyciel pracujący z nimi powinien więc zadbać o to, by niepotrzebnie nie narażać ich na dodatkowe zmęczenie, np. kiedy karta pracy przygotowana jest zbyt drobnym drukiem i dziecko z trudnościami percepcyjnymi musi włożyć dodatkowy wysiłek w odczytanie jej.

7. Odpowiednia przestrzeń wymagana do obsługi i rozmiar - zakłada, że produkt może być używany przez osoby o różnej posturze ciała, a także przez osoby mające trudność z poruszaniem się [DomagałaZyśk, 2015, s. 556]. 
Dbałość o stan przestrzeni w przedszkolu to jedno z podstawowych zadań statutowych dyrektorów placówek. Warunkami niezbędnymi do prowadzenia efektywnej edukacji przedszkolnej są, między innymi:

- tworzenie i rozwijanie strategii, kształtowanie i formułowanie wytycznych oraz stawianie wymagań, dzięki którym wzmocni się potencjał edukacyjny;

- zmiany/modyfikacje środków dydaktycznych, form organizacji zajęć oraz sposobów przekazywania treści, zawsze dostosowanej do wieku i możliwości odbiorców, środowiska ich pochodzenia i doświadczeń;

- zapewnienie bezpieczeństwa w przedszkolu, atrakcyjności pobytu w nim, dostępności pełnej oferty oraz pomieszczeń do wykorzystania na własne cele;

- dbałość o estetykę przestrzeni i otoczenia;

- zagospodarowanie przestrzeni dla konkretnego typu użytkownika wykorzystanie podstawowych danych antropometrycznych, które są pobierane w zależności od zapotrzebowania (rodzaju aktywności człowieka i przewidywanego sposobu wykorzystania obiektu, przestrzeni, czy przedmiotu);

- dostosowanie przestrzeni przedszkola do zakładanych celów programowych pod względem obiektów technicznych i infrastruktury [Nowacka, 2008, s. 18-26];

- stworzenie środowiska, które charakteryzować się będzie wartościami estetyczno-wizualnymi na równi ze zjawiskami dźwiękowymi, zapachem i dotykiem. Przestrzeń angażująca wszystkie zmysły człowieka staje się mu bardziej przyjazna i bezpieczna [Wysocki, 2012, s. 443-45];

- nawiązanie do funkcji edukacyjnej wewnątrz budynków;

- ukształtowanie przestrzeni opartej na zrozumieniu interakcji między trzema głównymi elementami: charakterystyką osobniczą uczestnika/użytkownika, charakterystyką obiektu pod kątem technicznym i eksploatacyjnym oraz środowiskiem. Pozwala ono określić wybór tematyki i programu oferty, jej treści merytorycznych, a także zakres działań edukacyjnych i miejsce działania; 
- w przypadku kształtowania przestrzeni dedykowanej dzieciom budowanie przestrzeni dydaktycznej dostosownej do potencjalnych możliwości dziecka, charakterystycznych dla jego przedziału wiekowego. Pamiętać przy tym należy, że cała przestrzeń życiowa dziecka jest zróżnicowana w swej strukturze i sile oddziaływania, tworząc swoiste środowisko edukacyjne [Domagała-Zyśk, 2015, s. 558].

Każda placówka, na skutek prowadzonych działań, osiągać powinna pełną gotowość do wdrażania rozwiązań i wprowadzania ulepszeń - skoncentrowanych na uniwersalnym projektowaniu w edukacji, a także przyjmowania dzieci niezależnie od specyfiki ich indywidualnych potrzeb. Oznacza to, że nie dopuszcza się do sytuacji, w której nie jest ona w stanie sprostać potrzebom uczęszczających do niej dzieci oraz nie dopuszcza się do istnienia barier, z którymi mogą się one potencjalnie borykać. Stworzenie placówki zaprojektowanej uniwersalnie, a zatem dostępnej dla wszystkich, nie jest prostym zadaniem. Wymaga bowiem szczególnego namysłu osób odpowiedzialnych za projektowanie i decydujących o ostatecznym obrazie placówki. Można to w pewnym stopniu odnieść do prostego przykładu z praktyki edukacyjnej: otóż w sali przedszkolnej dzieci podejmują różnorodną działalność, w tym czytanie książek. Czynność ta kojarzy się z zasiadaniem w miękkim fotelu lub przyjmowaniem luźnej, wygodnej pozycji. Tymczasem w salach przedszkolnych, a w szczególności w kącikach czytelniczych, brakuje specjalnie wyciszonych i wydzielonych przestrzeni „miękkich” i komfortowych, w których dzieci o różnych potrzebach i możliwościach percepcyjnych mogłyby spokojnie obcować z książką. Takich przykładów jest więcej, dlatego istnieje potrzeba szerszego spojrzenia na projektowanie przestrzeni, najlepiej uwzględniającego rozwój dziecka i jego udział w tym procesie.

Przełomem w nowym spojrzeniu na przestrzeń, w której dokonuje się proces edukacji dziecka, była realizacja w latach 2014-2015 w Uniwersytecie Przyrodniczo-Humanistycznym w Siedlcach projektu „Akademickie Centrum Kreatywności”2 ${ }^{2}$ W ramach projektu nawiązana została ścisła

\footnotetext{
2 Projekt współfinansowany przez Unię Europejską ze środków Europejskiego Funduszu Rozwoju Regionalnego na naukę, realizowany w ramach programu systemowego pn.
} 
współpraca z trzema „przedszkolami ćwiczeń” (Miejskie Przedszkole nr 15 w Siedlcach, Miejskie Przedszkole nr 3 w Siedlcach i Miejskie Przedszkole nr 25 w Siedlcach), w których odbywały się praktyki studenckie i prowadzone były badania w zakresie organizowania przestrzeni sprzyjającej edukacji dziecka i wyzwalającej jego kreatywność oraz wdrażania nowatorskich metod dydaktycznych. Ważnym i decydującym o wielu zmianach w siedleckich placówkach wydarzeniem, w ramach realizacji projektu, była wizyta studyjna w Uniwersytecie Komeńskiego w Bratysławie, w czasie której polskie i słowackie placówki mogły wymienić się dobrymi praktykami i wzajemnie korzystać ze swoich dokonań na polu jakości edukacji i projektowania przestrzeni [Wieruszewska-Duraj, 2015]. Warto nadmienić, że polskie przedszkola publiczne - o bardzo podobnym układzie architektonicznym, wybudowane w latach 70. - mają ograniczony rozkład oddziałów, traktowanych jako odrębne sale, bez specjalnie wydzielonego miejsca na jadalnię i sypialnie dla grup młodszych. Wiąże się to z tym, że w jednej sali mieścić się ma każda strefa - trzeba wydzielić miejsce na posiłki, leżakowanie/odpoczynek, zabawę, ruch. Nie jest to łatwe zadanie, zwłaszcza, że grupy są liczne - ok. 30-osobowe. W wyniku międzynarodowej współpracy i wymiany doświadczeń stworzony został uniwersalny model przedszkola - przyjaznego dziecku, odpowiadającego na jego potrzeby i potencjał rozwojowy, przy jednoczesnym zachowaniu specyfiki architektonicznej. Model zakładał sześć istotnych kryteriów, branych pod uwagę w organizacji przestrzeni dziecka:

1) grupa/oddział dzieci,

2) klimat sali przedszkolnej,

3) funkcjonalny podział przestrzeni sali,

4) organizacja przestrzeni,

5) aranżacja przestrzeni w aspekcie specyfiki rozwoju dzieci,

6) urządzenie i wyposażenie sali przedszkolnej - aranżacja stref sprzyjających uczeniu się dzieci.

W każdym z kryteriów postawione zostały zasadnicze problemy, wokół których prowadzona była analiza stanu faktycznego oraz próba ustalenia kierunku zmian. Na przestrzeni 5 lat (od 2015 r. do 2020 r.) do- 
konano modernizacji wyżej wymienionych placówek przedszkolnych i wprowadzono ulepszenia oraz zmiany aranżacyjne na korzyść przestrzeni dziecka. Wypracowany model ma charakter otwarty $i$ jest wciąż modyfikowany, a zmiany podyktowane są udziałem kolejnych dzieci i specyfiką ich rozwoju (w każdym cyklu projektu do przedszkoli uczęszczają inne dzieci), zmieniającą się rzeczywistością, realiami życia społecznego i ekonomicznego, zmianami w oświacie itp.

Ad 1. Grupa/oddział dzieci. Postawiony problem: Czy i w jaki sposób aranżacja przestrzeni sali przedszkolnej spełnia potrzeby dzieci, z którymi pracujemy? Istotną, z punktu widzenia powyższego kryterium, była liczebność i struktura grupy ze względu na płeć (podział na chłopców i dziewczynki), wiek (jednorodność wiekowa lub zróżnicowanie wiekowe), występowanie specjalnych potrzeb edukacyjnych oraz kulturę, z jakiej wywodzą się dzieci. W kryterium tym uwzględnione zostały również kwestie dotyczące indywidualnego tempa rozwoju dzieci oraz ich zainteresowań i uzdolnień.

Ad 2. Klimat sali przedszkolnej. Postawiony problem: Jak aranżacja sali wpływa na zmysły i samopoczucie dzieci, i czy wspiera ich układ nerwowy? Istotnym, z punktu widzenia powyższego kryterium, był dobór kolorów i materiałów w sali, jej oświetlenie, akustyka, dekoracje (sposób aranżacji) i panująca temperatura.

Ad 3. Funkcjonalny podział przestrzeni sali. Postawiony problem: Czy i w jaki sposób sala umożliwia optymalną realizację codziennych aktywności grupy? Istotnymi, z punktu widzenia powyższego kryterium, były kwestie występowania podprzestrzeni, w których dzieci mają możliwość: wspólnej pracy i zabawy całą grupą, zabawy w małych grupach, drzemki i odpoczynku w ciągu dnia, spożycia posiłków; a nauczyciele mają możliwość przechowywania materiałów i własne miejsce.

Ad 4. Organizacja przestrzeni. Postawiony problem: Czy przestrzeń jest efektywnie zorganizowana? Istotnym, z punktu widzenia powyższego kryterium, było określenie, czy przestrzeń jest optymalnie wykorzystana: Czy jest ona tak podzielona, że dzieci mogą przebywać i bawić się wspólnie, w małych grupach, oraz że możliwe jest także pobycie samemu? Czy przestrzeń w sali można elastycznie dostosowywać do zmieniających się potrzeb i pomysłów dzieci? W jaki sposób wykorzystuje się przestrzeń po- 
za salą (np. korytarz, hol przedszkola) na rzecz potrzeb dzieci i ich rodzin? W jaki sposób przechowuje się zabawki, sprzęt i materiały w sali i czy są one dostępne dla dzieci? Czy sprzyja to utrzymaniu porządku w sali?

Ad 5. Aranżacja przestrzeni w aspekcie specyfiki rozwoju dzieci. Postawione problemy:

a) W jaki sposób aranżacja sali sprzyja rozwojowi samodzielności dzieci? Istotnym, z punktu widzenia powyższego problemu, było określenie, czy meble i wyposażenie są dostosowane do wieku i wzrostu dzieci; czy portfolio, prace, plansze, tablice, zdjęcia, materiały i zabawki są udostępnione na wysokości wzroku i w zasięgu ręki dzieci; czy zabawki, materiały są dostosowane do potrzeb rozwojowych i zainteresowań dzieci; czy dzieci mogą samodzielnie i według własnego uznania aranżować swoją przestrzeń do zabawy, korzystając z ruchomych elementów wyposażenia typu parawany, materace, tkaniny, kartony, stoliki, krzesła; czy dzieci są włączane w projektowanie zmian w przestrzeni sali, w której przebywają na co dzień.

b) W jaki sposób w sali zapewnia się dzieciom bezpieczeństwo emocjonalne? Istotnym, z punktu widzenia powyższego problemu, było określenie, czy przestrzeń w sali jest stała i przewidywalna dla dzieci, czy w sali panuje domowa atmosfera, czy dzieci są uprzedzane o zmianach lub biorą udział w przeprowadzaniu zmian w otoczeniu, czy każde dziecko ma zapewnioną osobistą przestrzeń w sali.

c) W jaki sposób aranżacja przedszkola pozwala dzieciom orientować się $\mathrm{w}$ rozkładzie pomieszczeń i wyposażenia? Istotnym, z punktu widzenia powyższego problemu, było określenie, czy w przedszkolu znajdują się zrozumiałe dla dzieci oznaczenia miejsc i dróg pomiędzy pomieszczeniami, czy składowe wyposażenia sali (zabawki, materiały, środki i pomoce, miejsca) są czytelnie oznaczone i uporządkowane, czy osobiste rzeczy i miejsca dzieci są oznaczone i jak są oznaczone.

d) W jaki sposób przestrzeń sali sprzyja rozwijaniu relacji społecznych w grupie? Istotnym, z punktu widzenia powyższego problemu, było określenie, czy aranżacja sprzyja różnorodnym kontaktom między dziećmi i rozwojowi współpracy, czy przestrzeń sprzyja poszanowaniu różnorodności (płci, narodowości, kultur, ras). 
Ad 6. Urządzenie i wyposażenie sali przedszkolnej - aranżacja stref sprzyjających uczeniu się dzieci. Postawiony problem: W jaki sposób aranżacja stref w sali sprzyja uczeniu się dzieci i koresponduje ze specyfiką rozwoju dziecka? Istotnym, z punktu widzenia powyższego problemu, było określenie: Czy w sali uwzględniono wszystkie strefy aktywności, także ze względu na wiek i zainteresowania dzieci (np. strefa czytelnictwa, strefa konstruowania, strefa doświadczania, strefa manipulowania, strefa wyciszenia, strefa ekspresji artystycznej, strefa aktywności ruchowej itd.)? Czy wielkość danej strefy jest odpowiednia do aktywności i liczby dzieci? Czy wyposażenie danej strefy jest wystarczające i dobrej jakości? Jak możemy je uzupełnić? Czy strefy aktywności są logicznie uporządkowane i praktycznie wydzielone?

Na przykładzie zmian, jakie wprowadziły i nadal skutecznie wprowadzają w swej przestrzeni trzy siedleckie przedszkola, można stwierdzić, iż możliwe jest zaprojektowanie uczącej, elastycznej i wielofunkcyjnej przestrzeni z przyjazną i spokojną atmosferą wnętrz, pozwalającą dzieciom na zaspokojenie różnorodnych potrzeb, na różne formy aktywności oraz zapewniającą nauczycielom komfort pracy z nimi.

\section{Literatura}

Domagała-Zyśk E. (2015), Projektowanie uniwersalne w edukacji osób z wadq słuchu, [w:] M. Nowak, E. Stoch, B. Borowska (red.), Z problematyki teatrologii i pedagogiki, Wyd. KUL, Lublin.

Konwencja ONZ o prawach osób niepełnosprawnych (Dz. U. 2012 poz. 1169).

Nowacka Ł. (2008), Kształtowanie przestrzeni z punktu widzenia zróżnicowanego odbiorcy - antropometria jako narzędzie w projektowaniu, „Studia i Materiały Centrum Edukacji Przyrodniczo-Leśnej”, R. 10, z. 2 (17).

Ustawa z dnia 19 lipca 2019 r. o zapewnianiu dostępności osobom ze szczególnymi potrzebami (Dz. U. z 2019 r. poz. 1696).

Wieruszewska-Duraj S. (2015), Technika doświadczeń poszukujq̨cych w nabywaniu i kreowaniu wiedzy ekologicznej przez dzieci 5-letnie, Pracownia Wydawnicza Wydziału Humanistycznego UPH w Siedlcach, Siedlce.

Wysocki M. (2012), Przestrzeń dostępna - wyzwania społeczne i projektowe, „Czasopismo Techniczne", t. 1-A/2, z. 1. 